\title{
PHENOMENOLOGICAL WAYS FOR RETHINKING ARCHITECTURE
}

\section{A B S T R A C T}

Returning to a long and fruitful anthropological tradition, which has flourished from phenomenological-hermeneutical thought, I propose an understanding of the human being as "bodily conscience" or "embodied conscience". Unlike objects, human beings have a relationship with space which is intrinsic to their existence. My aim is to delve deeper into the meaning of this "human dwelling" with special reference to the questions of building and projecting. Places are not mere contexts, mere backgrounds where events and activities take place, but rather they play an active role in the building of relationships, groups, imagination, and self-awareness.

\section{Carla Danani}


STEMMING FROM A GOOD IDEA...

Corviale was built on the outskirts of Rome between 1975 and 1982: it is a residential project organised in two back-to-back linear buildings, 958 meters long, 200 meters wide, and 30 meters in height. There are 1,202 apartments housing 8,000 occupants. Conceived as an independent community for about 8,000 people, which would include facilities such as schools, shops, recreational spaces and even a church, the building was based on the idea of social housing to provide all the necessary infrastructure of a city within the complex itself, and to encourage social interaction among its occupants.

One can say that Corviale was built with reference to the idea of Le Corbusier's rationalistic Utopia, but Romano De Simoni (who was part of the group of designers behind this project) says that this can be true with respect to its size and volume rather than the ideology inspiring it. The design plan for the entire project outlines its breath and depth. Corviale was intended, not as a system for rational habitation, but to promote social aggregation, communitarian and solidaristic ties, that is: with a strong social intention.

But some links in the chain fell through. The fourth floor, which should have been the heart of the project (with several shops, common rooms and services), was illegally occupied. Many of the originally planned structures were never built or remain unfinished, almost 20 years since the first occupants moved into it. The area lacks an adequate metropolitan infrastructure and it remains isolated from the greater city which it was intended to be a part. Irene Ranaldi from the Association "Ottavo Colle" underlines the silence which reigns here, psychiatrist Antonello d'Elia notes the sense of neglect one feels here: Corviale is a monolith, which does not communicate to the city.

Therefore, people living here know that basing a view of Corviale solely on a premise on its difficulties is part of its problems and would like to see that this negative narrative be changed. Many practices have been involved in trying to change the imaginary and to foster different experiences for Corviale's residents. The complex has five auditorium spaces designed for citizens' meetings, which have never been used - so much so that in recent years some artists have started referring to them as "The Trees Hotel". Aptly named after a group of young people began to grow trees in one of the auditoriums under the supervision of Ester Stocco, a local psychologist. The idea is continuing on and many residents now grow their own trees here. The tree has become a medium for a new identity of this place, without any rebuilding or removing old graffiti. Calciosociale and Radio Impegno are other relevant experiences. Calciosociale 
practices a type of a football game with new rules and a very big social impact, with Radio Impegno live streaming it at night, highlighting the fact that this place is alive, at night as well.

Corviale is a relevant architectural question, which reveals a tension between everyday experiences that this place allows, the new ones which are created for a better living and the project from which Corviale originated. From this tension a question arises: Is there generally an aporia that affects the designing in itself?

\section{THE PROJECT AS A QUESTION}

Jean Francois Lyotard criticises every "project" in itself, as referred to the modern idea of progress. He says that a project is always a promise of a conclusive solution to the angst of dwelling and to the modern humiliation of being "quartered". A project is a promise of harmony for everyone and among all human beings in the habitable space-time.

There is violence in the realisation of this promise. Is it possible to get away from this violence? Lyotard is cautioning us about the paradox that to project the reversal of the modernity project is still a project. He changes the question itself and asks how such a "weak-architecture" can exist. ${ }^{1}$

To understand Lyotard's thought one must take a step back to the beginning of the Modern Era. René Descartes, in his Discours de la Méthod (1637), said that old knowledge is like old cities, which are built randomly, without a project or any order, without such regularity which is only given by an engineer through a project. In these cities all the streets are irregular and one can say that they were built by fate. Conversely, one has to start from a well-defined project, which an engineer has to fulfil. A well-defined project develops from reason only and from clear and distinct ideas.

Descartes holds that reason means pure reason. It is something independent from the body. From Descartes' point of view a proper building arises only from this pure reason: the good thinking has no premises and no authority to adapt to, it moves from itself.

But one can ask if Descartes' meaning is really the only one about the notion "project". The word derives from the Latin projectum, neuter past participle of proicere "throw forth", from pro- "forth" added to jacere "to throw". 
Massimo Cacciari makes a distinction among many meanings. ${ }^{2}$ For the first one, a project is something which pre-empts and launches an intentional act, which is directed to the realisation of something new. The project defines an end and moves to its realisation forcing all obstacles. It involves a question about the right means of securing a certain result. The second one understands the project as something going beyond, moving away. To project is to distance oneself from what is already given. It is not possible to define its end or its goal, because it is indefinite. A third meaning arises from the idea that Dasein is Entwurf, not by choice but from an ontological point of view. Entwurf is not Fort-schritt, it means radical possibility. ${ }^{3}$

Cacciari considers that nowadays these multifocal meanings of the word "project" are lost; people usually understand it as a productive anticipation which includes the means useful for its realisation. The space-time that is between the starting point and the final result is understood only as the way to the goal and the ideal would be the mere deduction of it from the starting point. He advocates that there is an aporia. Freedom and necessity should go together. On the one side the project is understood as perfectly self-sufficient and free from any bonds, premises and conditions; novelty is declared in first place. On the other it is an established strategy which has to ensure both this total free happening and this very novelty from the ouset. Moreover, a project cannot free itself from the anticipation from which it starts, the thought from which it arises is its premise and condition.

I hypothesise that Descartes' point of view is at the core of this aporetic idea of project. It lies in the mind-body dichotomy, that involves the mind-world dualism in which body and world are mere receptacles. However, this is not the only way of thinking about a "project".

\section{RETHINKING “PROJECT”}

Edmund Husserl departs from Descartes' perspective, but he criticises it because it is not possible to start from "first evidence" as something completely primary, separated from time and language. In Die Krisis der Europäischen Wissenschaften Husserl denounces that sciences must always belong to a field of relations among forms of life. He affirms that nobody saying "I think" is reducible to this "I think" for he or she is also a body. Moreover, no one creates his/her own body. ${ }^{4}$ In Erfahrung und Urteil Husserl describes how a meaning expressed by the apophantic judgement (like: sis $p$ ) can be traced back to the perceptual meaning from which it has roots. This last determines itself 
progressively in the antepredicative experience, which has its own constitutive autonomy. The point here is experience. The result of Husserl's analyses is that meaning, which originates at ante-predicative level cannot be the work of a transcendental ego that constitutes it outside of space and time. It is the work of a consciousness embedded in a historical becoming. Passivity characterises the pre-reflective dimension of experience, which is the experience of some pre-givenness of object-like formations. This dimension is the basis of activity. Something does give itself in perception as a whole object, but by its very nature it does so "paradoxically" incompletely, in and through perspectives or modes of givenness. ${ }^{5}$ Husserl says that the object in itself is taken as such by us, which is to say: the in-itself is only constituted as in-itself-for-us. Part 3 of the Analyses picks up precisely here with the descriptions of higher and higher levels of attention and processes of active objectification. Passivity and activity are really only phenomenologically designated internal differentiations of cognitive experience, because we can only gain the level of experience of passivity for reflection by presupposing and abstracting from the accomplishments of activity. Even if departing from Descartes, Husserl highlights the relevance of experience in the life-world.

In the 1940s in Paris, Maurice Merleau-Ponty in his Phenomenologie de la Percéption developed Husserl's phenomenology emphasising the role of the body in human experience. Merleau-Ponty describes his embodied form of phenomenology in these words:

"Insofar as, when I reflect on the essence of subjectivity, I find it bound up with that of the body and that of the world, this is because my existence as subjectivity is merely one with my existence as a body and with the existence of the world, and because the subject that I am, when taken concretely, is inseparable from this body and this world." 6

This means consciousness is embodied (in the world) and the body is "infused" with consciousness.

Starting from a phenomenological approach but gaining inspiration from biology and ecological psychology, Tim Ingold stresses the relationship between human beings and their world. He says that human beings belong to the earth and their environment. From this point of view, he highlights the "limits of design". He refuses the so-called building perspective, in which the project and its execution are separated, because of its premise on live beings. He proposes a "dwelling perspective", in which the core is the concrete and daily "being in the world" of human beings. Ingold clarifies that "dwelling perspectives" means a perspective "that treats the immersion of the organism-person in an 
environment or lifeworld as an inescapable condition of existence". ${ }^{7}$ He says that "life, in this perspective, is not the revelation of pre-existent form but the very process wherein form is generated and held in place." departure is the agent-in-its-environment, or what phenomenology calls "being in the world", as opposed to the self-contained individual confronting a world "out there". One must not renounce any projecting, but rather understand it as a kind of collaboration between the aim to give forms and on what it applies itself. ${ }^{9}$ If Plessner thought that human beings are open to the world because of heimatlos, without any home, Ingold says that they are part of the earth and environments where they live with other organisms. The world is not a tabula rasa on which one has to exercise its ability to project, nor a container to which to adapt oneself.

How to reimagine human beings as part of a larger whole? Ingold proposes the idea of meshwork:

"In this depiction there is no inside or outside, and no boundary separating the two domains. Rather there is a trail of movement or growth. Every such trail discloses a relation. But the relation is not between one thing and another - between the organism 'here' and the environment 'there'. It is rather a trail along which life is lived. [...] Each such trail is but one strand in a tissue of trails that together comprise the texture of the lifeworld. This texture is what I mean when I speak of organisms being constituted within a relational field. It is a field not of interconnected points but of interwoven lines; not a network but a meshwork."10

Ingold refers to Deleuze's thinking and he underlines the importance of distinguishing the network as a set of interconnected points from the meshwork as an interweaving of lines. Here the lines are not connecting points of the network but the paths along which life is lived.

From the idea of meshwork follows a differentiation between two ways of "to make": an end-directedness making and an intransitive participatory making, the co-aptatio. Co-aptation is opposite to construction: although "apt" for a current purpose, something is not especially built for this. ${ }^{11} \mathrm{He}$ uses the term wayfaring to describe the human embodied experience, which is not fundamentally place-bound, but place-binding. It is true that human beings - perhaps uniquely among animals - have the capacity to envision forms in advance of their implementation, but this envisioning is itself an activity carried out by real people in a real-world environment, rather than by a disembodied intellect existing in a subjective space containing problems it seeks to solve. ${ }^{12}$ 
One can find here some suggestions about the meaning of "project", for escaping the "building perspective". One cannot say that people import their ideas, plans or mental representations into the world, since that very world - to borrow a phrase from Merleau-Ponty ${ }^{13}$ - is the homeland of their thoughts. Only because they already dwell therein can they think the thoughts they do.

From a phenomenological perspective and referring to one of the most important Japanese philosophers of the twentieth century, Watsuji Tetsurô, Augustin Berque offers an important contribution working to reject the notion of environment as too objectivist. He advances a distinction between a western concept of landscape, pivoted around the subject, and an eastern concept which focuses on the predicate instead. Berque explains that for Tetsurô the crucial notion of füdo can be found, which contrary to a superficial impression, does not entail a deterministic approach (i.e. the idea that the place determines the mores and ethos of people). Berque proposes to translate fûdo as médiance, something that simultaneously mediates and exists is in the middle of the relationship between our society and the environment. He speaks of milieu, a concept which inherently entails a point of view from inside such a relationship, and of ecoumène to address the phenomenon of the birth of a plurality of lifeworlds through progressive unfolding and development of milieus. Hence, if the médiance is always a local and "emplaced" relationship between humans and their milieu, a reciprocal "absorption" between a place and its inhabitants, the ecoumene is the human relation to the geographic extension of the planet at large.

If Husserl and Merleau-Ponty highlight the world of life and the embedded experience of human beings, Ingold and Berque bring forward the phenomenological point of view reflecting the field where experiences occur. They all offer very relevant elements for a phenomenological way for rethinking "project". With them we understand that architects, and designers in general, cannot "work" autonomously, without references.

\section{ARCHITECTURE AND NARRATIVITY}

Departing from a hermeneutic-phenomenological method, Paul Ricoeur offers a reflection about the architectural practice itself. He bases it on an anthropological perspective because human beings are residing-wandering beings, relational beings who relate with themselves and with others. Place cannot be read as an abstraction expressing Cartesian coordinates of the geometric space, where the points are all equivalent. It is a living place for living bodies. 
In an article entitled Architecture and Narrativity he considers that the common ground between narrativity and architecture is time, and describes the architectural work as a negotiation between spaces of experience and horisons of expectation. In architecture he discovers three stages of the triple mimesis of the time, namely prefiguration, configuration and refiguration. Prefiguration refers to "the act of inhabiting" as presupposition of building; here the narrative is tied to everyday life. Ricoeur maintains that both the architect and the narrator activate the same human faculty - "anticipation", and occupy the same human dimension of time - "present of the future". Configuration refers more directly to "the act of building" that takes charge of inhabiting. The act of construction can be understood as the spatial equivalent of the narrative configuration by plotting. Refiguration institutes a level of exchange between the "act of inhabiting" and the "act of building". Ricoeur says:

"It is time to talk of inhabiting as a response, even as an answer to building, on the model of the agonistic act of reading, because it will not suffice for an architectural project to be well thought-out, or even for it to be held to be rational for it to be understood and accepted. All planners ought to learn that an abyss can separate the rules of the rationality of a project - that is true for all politics, moreover - from the rules of acceptability to a public. We must therefore learn to consider the act of inhabiting as a focus not only of needs, but of expectations. And the same palette of responses as earlier can be travelled, from passive reception, subdued, indifferent reception, to hostile and angry reception - even that of the Eiffel Tower in its day!"14

We can say that "receptive and active inhabiting imply a careful rereading of the urban environment, a continuous relearning of the juxtaposition of styles, and thus of life stories of which the monuments and all the buildings carry the traces." ${ }^{15}$ But "we must therefore mourn the total understanding and admit that there is something inextricable in the reading of our towns." 16

When in Memory, History, Forgetting, Ricoeur addresses these themes (in the chapter Inhabited Space), he no longer speaks about the lived space beginning from time, but he starts his reflection from space, with the living body being the starting point. The reflection ranges from built spaces to geography, and the relationship between space and human beings is called "open to practice as well as to perception". 


\section{MANY QUESTIONS REMAIN AND SOME PATHS OPEN}

The proposed reflections and key notions offer some suggestions for many paths of thinking in order not to remain at Descartes' autonomy of the intellectual reason.

Our first question was: Is Descartes' meaning the only one about the notion of project? The second one: Descartes' point of view about the mind-body dualism that involves the mind-world dualism is at the core of an aporetic idea of project. Are there different ways of thinking? Furthermore, we can ask: Is it possible for human beings not to project? How can we project, if we have to project at all?

I call the path I propose in this paper a perspective for "sensible wisdom". It concerns the awareness "to be in the world" as in a space-time game with others; it implies intellectual efforts, active practices, refinement of sensibility as well as complexity of thoughts, and it implies broadening one's horizons and paying attention to little details as well.

Merleau-Ponty observes in L'oeil et l'esprit: "Science manipulating things and give up living in them". After these words at the very beginning of his text, he says that science is an admirably active, ingenious, and bold way of thinking, but its "fundamental bias is to treat everything as though it were an object-ingeneral - as though it meant nothing to us and yet was predestined for our own use." ${ }^{17}$ The scientific thinking, which is used to look on from above (pensée de survol) and to think of the object-in-general, must return to the "there is" which precedes it. This means that it has to return

"to the site, the soil of the sensible and humanly modified world such as it is in our lives and for our bodies [...]. Furthermore, associated bodies must be revived along with my body - "others", not merely as my congeners, as the zoologist says, but others who haunt me and whom I haunt." 18

This means to acquire place-consciousness, which calls for a haptic perspective. But what are places? We can conclude that places "happen", instead that they merely "are"... 

Triennale di Milano. XIX Esposizione Internazionale (Milan: Electa, 1996), 54.

Massimo Cacciari, "Nihilismo e progetto," Casabella 483, (September 1982): 50-51.

Martin Heidegger, Being and Time, trans. John Macquarrie, and Edward Robinson (Oxford: Blackwell, 2001), §§ 31-32.

Edmund Husserl, The Crisis of European Sciences and Transcendental Phenomenology. An Introduction to Phenomenology, trans. David Carr (Evanston-IL: Northwestern University Press, 1970), 384 .

Edmund Husserl, Analyses concerning passive and active synthesis : lectures on transcendental logic, trans. Anthony J. Steinbock (Dordrecht -The Netherlands: Kluwer Academic Publishers, 2001), 39

Maurice Merleau-Ponty, Phenomenology of Perception, trans. Colin Smith (London and New York: Routledge, 2002), 475.

Tim Ingold,. The perception of the Environment. Essays in Livelihood, Dwelling, and Skill (London: Routledge 2000), 153. 
Tim Ingold, Being Alive. Essays on Movement, Knowledge and Description (London Routledge: 2011), 173. Ingold, Evolution, 418-419.

Paul Ricoeur, "Architecture and narrativity,” Trans. by Eileen Brennan, Robbie Carney and Samuel Lelièvre. Études Ricoeuriennes / Ricoeur Studies 7, no. 2 (2016): 38. Northwestern University Press, 1964), 159

Berque, Augustin. Mesologics: The Argument. 2012. Available at: http://ecoumene.blogspot.fr/p/ argument-english-version.html.

Cacciari, Massimo. "Progetto.” Laboratorio Politico, no. 2, I (1981): 88-119.

Cacciari, Massimo. "Nihilismo e progetto.” Casabella 483 (September 1982): 50-51.

Cacciari, Massimo. Architecture and Nihilism: On the Philosophy of Modern Architecture. Translated by Stephen Sartarelli. New Have: Yale University Press, 1993.

Heidegger, Martin. Being and Time. Translated by John Macquarrie and Edward Robinson. Oxford: Blackwell, 2001, orig. 1929.

Husserl, Edmund. Analyses concerning passive and active Synthesis : Lectures on transcendental Logic. Translated by Anthony J. Steinbock. Dordrecht (NL): Kluwer Academic Publishers, 2001, orig. 1918-26.

Husserl, Edmund. The Crisis of European Sciences and Transcendental Phenomenology. An Introduction to Phenomenology. Translated by David Carr. Evanston-IL: Northwestern University Press, 1970, orig. 1936. 
Husserl, Edmund. Experience and Judgment. Translated by James S. Churchill and Karl Ameriks. Evanston -IL: Northwestern University Press, 1973, orig. 1948.

Ingold, Tim. Evolution and social life. Cambridge: Cambridge University Press, 1986.

Ingold, Tim. The perception of the Environment. Essays in Livelihood, Dwelling, and Skill. London: Routledge, 2000.

Ingold, Tim. Being Alive. Essays on Movement, Knowledge and Description. Routledge: London, 2011.

Lyotard, Jean Francois. Postmodern Condition. Translated by Geoff Bennington and Brian Massumi. Manchester: Manchester University Press, 1984, orig. 1979.

Lyotard, Jean Francois. "Identità e immaginario postmoderno." in AA.VV., Identità e differenza, Triennale di Milano. XIX Esposizione Internazionale. Milan: Electa, 1996, 46-55.

Merleau-Ponty, Maurice. Phenomenology of Perception. Translated by Colin Smith. London and New York: Routledge, 2002.

Merleau-Ponty Maurice. The Primacy of Perception. Translated by James M. Edie. Evanston (IL): Northwestern University Press, 1964.

Merleau-Ponty Maurice. The Visible and the Invisible. Translated by Alphonso Lingis. Evanston (IL): Northwestern University Press, 1968.

Nishida, Kitarô. Place and Dialectic: Two Essays by Nishida Kitarō. Translated by John W.M. Krummel and Shigenori Nagatomo. Oxford and New York: Oxford University Press, 2012 (contents: Basho, 1926/27; Logic and Life, 1936/37).

Ricoeur, Paul. "Architecture and narrativity." Translated by Eileen Brennan, Robbie Carney and Samuel Lelièvre. Études Ricoeuriennes / Ricoeur Studies 7, no. 2 (2016): 31-42.

Ricoeur, Paul. Memory, history, forgetting. Translated by Kathleen Blamey and David Pellauer. Chicago: University of Chicago Press, 2004.

https://www.corviale.com

https://www.corvialedomani.it 


\section{PROSTORI ZA PROMIŠLJANJE - GDE JE MESTO FILOZOFIJE? \\ Ludger Schwarte}

Ako rezonovanje podrazumeva određenu arhitekturu (koncepata), čin rezonovanja nije nezavisan od vrlo konkretnih arhitektonskih dispozicija. U svom radu ću, za početak, dati skicu mesta, koja su projektovana kao prostori za promišljanje, zatim dekonstruisati implicitne pretpostavke odnosa sa arhitekturom, i na kraju, pokušati da pokažem kako praksa filozofije zavisi od arhitektonske postavke.

KLJUČNE REČI: FILOZOFIJA, ARHITEKTURA, PROSTOR ZA PROMIŠLJANJE

ISTRAŽIVANJE IDEJA NAŠIH ČULA

ISTRAŽIVANJE KANTOVE SPOSOBNOSTI MAŠTE U UNGEROVIM

"METAFORAMA GRADA"

\section{Andrea Weigt}

Čula i ideje, kako se oni susreću? Povezanost sfere čula i čistog uma se nalazi u filozofiji Imanuela Kanta, posebno u njegovoj teoriji o ljudskoj sposobnosti maštanja. Ovaj tekst analizira njegove ideje u pogledu tog svojstva, a posebno koncepta slobodne igre. Kroz primere kreativnih procesa arhitekata, pokazaću kako slobodna igra između sposobnosti mašte i spoznaje menja našu percepciju. U tom stanju percepcije, ideje nastaju iz naših čulnih inputa. Osvald Ungers (Oswald M. Ungers) je dalje obrazložio da ideja daje život njegovim kreacijama u svojoj publikaciji "Metafore grada", koja je i glavna referenca ovog rada. Po njegovom tumačenju, "Metafore grada" mogu temeljno pokazati ovo izmenjeno stanje percepcije ukoliko je povezano sa Kantovim teorijama i njegovim shvatanjem mašte. "Metafore grada" mogu čak biti posmatrane i kao istraživanje mašte koje zadire u slobodnu igru. U svom zaključku ću koristiti projekte Le Korbizjea i Alvara Alta kako bih ilustrovala značaj mašte $u$ datim primerima projektantskog procesa.

KLJUČNE REČI: MAŠTA, PROJEKTOVANJE, KREATIVNOST, SLOBODNA IGRA, ŠEMA, TRANSCENDENTALNA

FILOZOFIJA, OSVALD UNGERS, IMANUEL KANT, KRITIKA RASUĐIVANJA

\section{FENOMENOLOŠKI NAČINI ZA PROMIŠLJANJE ARHITEKTURE}

\section{Carla Danani}

S osvrtom na dugu i antropološku tradiciju, koja je procvetala iz fenomenološke i hermeneutičke misli, predlažem razumevanje ljudskog bića kao "telesna savest" ili "otelovljenje savesti". Za razliku od predmeta, ljudska bića imaju vezu sa prostorom, koja je suštinska za njihovo postojanje. Moj cilj je da produbim značenje ovog "ljudskog bitisanja" s posebnim osvrtom na pitanja izgradnje i projektovanja. Mesta nisu samo kontekst, puke pozadine gde se događaji i aktivnosti odvijaju, već ona igraju aktivnu ulogu u izgradnji odnosa, grupa, mašte i samosvesti.

KLJUČNE REČI: PROJEKAT, MESTO, VREME, TELO, PAMĆENJE, MESTO STANOVANJA, SREDINA

\section{ŠETAČ (FLANEUR) U TORINU \\ PERCEPCIJA PROSTORA U RADOVIMA FRIDRIHA NICEA I VALTERA \\ BENJAMINA}

\section{Theresa Rauch}

Ovaj rad će pokušati da napravi razliku izmedju tri različite vrste prostorno-atmosferskog iskustva na osnovu teorija Hermana Šmitsa (Hermann Schmitz) i Roberta Višera (Robert Vischer). Osim toga, rad povezuje ove metode sa likom šetača (flaneur) u knjizi "Odlomci Valtera Benjamina" (Walter Benjamin's Passages) kao i dnevnicima o Torinu Fridriha Ničea (Friedrich Nietzsche). Ova dva koncepta flaneur-a se mogu posmatrati kao konfliktna. Za Benjamina je šetnja gradom sredstvo intelektualne stimulacije, sa fokusom na impulse iz urbanog pejzaža koji se zatim 